\title{
Studies on colour fixation of the oil of mature, immature and damaged cottonseed
}

\author{
By H. E. Helmy, A. S. El-Nockrashy and H. M. El-Noamany.
}

\author{
Oils and Fats Dept., National Research Centre, Dokki, Cairo, Egypt.
}

\section{RESUMEN}

Estudios sobre la fijación de color de aceite de semilla de algodón, madura, inmadura y dañada.

Se extrajo aceite de semila de algodón madura, inmadura y dañada con el azeotropo, acetona-hexano-agua $(53: 44: 3 \mathrm{v} / \mathrm{v} / \mathrm{v})$. Se sometieron a diversos tratamientos tales como refinación y decoloración, silicato sódico antes de la refinación y decoloración o antes de la fijación de color, a aceite de semilla de algodón madura (M), $10 \%$ de aceite de semilla de algodón inmadura en aceite de semilla de algodón madura (MIM) y $10 \%$ de aceite de semilla de algodón dañada en aceite de semilla de algodón madura (MD). Los aceites tratados se estudiaron espectrofotometricamente.

La presencia de un $10 \%$ de aceite de semilla de algodón inmadura o dañada con aceite de semilla de algodón madura produjo un incremento en el color y en el espectro de absorción de la mayoría de las muestras, así ocurrió en un aceite que no pudo ser refinado y decolorado satisfactoriamente. El tratamiento con silicato sódico resultó efectivo antes de la refinación y fijación del color de los aceites. El estudio reveló la presencia de pigmentos gosipol, carotenoides y clorofilas en diferentes muestras M, MIM y MD.

PALABRAS-CLAVE: Aceite - Fijación de color - Semilla de algodón dañada - Semilla de algodón inmadura - Semilla de algodón madura.

\section{SUMMARY}

Studies on colour fixation of the oil of mature, immature and damaged cottonseed.

Oil was extracted from mature, inmature and damaged cottonseed with the acetone-hexane-water azeotrope ( $53: 44: 3$ by volume). Mature cottonseed oil (M), 10\% immature cottonseed oil in mature cottonseed oil (MIM) and 10\% damaged cottonseed oil in mature cottonseed oil (MD) were subjected to some treatments e.g. refining and bleaching or the addition of sodium silicate before refining and bleaching or before colour fixation. The treated oils were spectrophotometrically studied.

The presence of $10 \%$ oil from immature or damaged cottonseed in oil from mature cottonseed produced an increase in the colour and absorption spectra of most samples, resulting in an oil that could not be refined and bleached satisfactorily. Sodium silicate proved to be an effective treatment before refining and colour fixation of the oils. The study revealed gossypol pigments, carotenoids and chlorophylls present in different $\mathrm{M}, \mathrm{MIM}$ and MD samples.

KEY-WORDS: Colour fixation - Dammaged cottonseed - Immature cottonseed - Mature cottonseed - Oil.

\section{INTRODUCTION}

The well known problem of darkening of crude cottonseed oil has been generally known as "colour fixation". Dark oil requires a substantial excess of fairly strong alkali solution in refining process to remove the colour. This excess alkali promotes excessive losses due to saponification of neutral oil (Attia et al., 1981; Berardi, 1957; El-Nockrashy et al., 1976a; Osman, 1976; Helmy, 1985 and Attia, 1988). The fixation of undesirable colours can develop during storage of the seed prior to processing in immature of damaged seeds, or can brought about by conditions existing during processing of the seed (Williams, 1947). Cottonseed becomes mature when no further changes in depositions of its constituents take place, and no further growth occurs (El-Nockrashy et al., 1976b), it does not show any sign of discolouration, moldgrowth and breakage. Immature seed obtained from immature bolls, which have been prematurely broken open by frost or other climatic or non-climatic factors, immature seed is much smaller than the sound mature seed, it has rudimentary kernel and usually has pale reddish hull (Fash, 1934). Several factors cause damage to cottonseed in the field, during transportation, storage and exposure of the boll to varying weather conditions e.g. excessive rain-fall, high atmospheric humidity, attack of insects, rats, birds and fungi or by mechanical instruments in the field or during seed storage (Bailey, 1948). Damaged as well as immature seeds fail completely to germinate.

The objective of the present study is to investigate the effect of mature, immature and damaged cottonseed pigments on colorur fixation of the oil, and to study the effect of some treatments on the oil from these seeds.

\section{EXPERIMENTAL}

Material: Cottonseed (Gossypium barbadense) used in the present study was kindly supplied by the Cottonseed Research Institute of the Ministry of Agriculture. The seed was manually separated into three seed types; mature, immature and damaged cottonseed.

Oil Extraction: Oil of the dehulled and finely ground cottonseed of the theree types was extracted in a Soxhlet apparatus using the "acetone-hexane-water" azeotrope ( $55: 44: 3$ by volume) to offer the maximun recovery of oil and pigments and to allow better understanding of the effect of pigments on the colour fixation of the oil.

Refining of the Crude Oils: Cottonseed oil samples were refined according to the Official Methods of the AOCS (1980). 
$25 \mathrm{gm}$ cottonseed oil samples were place in $100 \mathrm{ml}$ beakers. Calculated amount of sodium hydroxide solution ( $\left.18^{\circ} \mathrm{Bé}\right)$ was added gradually to each sample during stirring mechanically in a water bath at $60^{\circ} \mathrm{C}$ for $30 \mathrm{~min}$, based on the percentage of free fatty acids. The resulting mixture was left to settle, then centrifuged at high speed $(3000 \times \mathrm{g})$ for 15 $\min$. The oil layer was decanted in a stoppered bottle and kept in a dark cool place for further use.

Bleaching of the Refined Oils: Bleaching of the refined oils was carried out according to the Official Methods of the AOCS (1980).

The refined oils (20 gm each) were weighed in $100 \mathrm{ml}$ beakers and heated in an oil bath at $110^{\circ} \mathrm{C}$. Bleaching earth "Tonsil" was added at $3 \%$ of the oil weight, while stirring for $10 \mathrm{~min}$. The mixture was cooled, left for precipitation,then centrifuged at high speed $(3000 \times \mathrm{g})$ for 15 $\min$. The oil layer was decanted in stoppered bottle and kept in a dark cool place for further use.

Colour Fixation: Crude oil samples placed in $100 \mathrm{ml}$ beakers were subjected to the accelerated colour fixation treatment by heating in an oven at $60^{\circ} \mathrm{C}$ for 15 days as described by Pons et. al., (1962) and recommended by others (Pons et. al., 1959 and Pons, 1960). The crude oils became crude colour-fixed oil.

Sodium Silicate Treatment of Cottonseed Oil: Crude cottonseed oils and colour-fixed cottonseed oils are treated with sodium silicate according to Attia et al., (1988).

A boiling supersaturated solution of sodium silicate $(47 \%)$ at $0.23 \%$ of the crude oil weight was added simultaneously to the oil with $75 \%$ of the calculated amount of sodium hydroxide solution ( $\left.18^{\circ} \mathrm{Bé}\right)$ required for refining while stirring and heating the oil in a water bath at $65^{\circ} \mathrm{C}$ for $30 \mathrm{~min}$.

Samples were allowed to settle, then centrifuged at $3000 \mathrm{xg}$ and the oil layer was decanted.

Spectrophotometric Analysis: Absorption spectra of oil samples were determined using the Shimadzu UV-Visible Recording Spectrophotometer 240 with a wave-length range from 300 to $700 \mathrm{~nm}$. In order to get a reasonably representative absorption curve, crude oil samples have been diluted with $\mathrm{CCl}_{4}$ at a ratio of $1: 500$ by volume, whereas refined and bleached oils were diluted with the same solvent at a ratio of 1:20 or studied without dilution.

Oil Colour: Colour index method which determines the area under the absorption spectra curve in the region from 400 to $550 \mathrm{~nm}$ and recommended by Pons et al. (1960, 1962) was used.

A total of 16 readings were taken with $10 \mathrm{~nm}$ difference within the $400-550 \mathrm{~nm}$ range. $\mathrm{CCl}_{4}$ was used as a blank. The sum of 16 O.D. readings are multiplied by 10 to give an approximation for the area under absorption curve. The product is designated as the colour index, which indicates the concentration of the colouring matter in the oil.

Refinability, Bleachability and the Overal Effect of the Treatment on Oil Colour:

$$
\text { Refinability }=\frac{C-R}{C} \times 100
$$

$$
\begin{aligned}
& \text { Bleachability }=\frac{R-B}{R} \times 100 \\
& \text { Overall Effect }=\frac{\text { C - B }}{C} \times 100
\end{aligned}
$$

Where $\mathrm{C}=$ Crude oil colour, $\mathrm{R}=$ Refined oil colour and $\mathrm{B}=$ Bleached oil colour

Treatments on Oil from Mature (M), Mature containing 10\% Immature (MIM) and Mature containing 10\% Damaged (MD) Cottonseed:

See the figure of the schematic representation of the different treatments that were carried out on crude oil from mature, mature/immature and mature/damaged seed.

Treatment I: Conventional refining and bleaching of crude oil.

Crude cottonseed oil from M, MIM or MD $(25 \mathrm{~g})$ was refined and bleached.

Symbols of these oils are:

$M-C$, MIM-C and MD-C

$\mathrm{M}-\mathrm{R}, \mathrm{MIM}-\mathrm{R}$ and $\mathrm{MD}-\mathrm{R}$

for crude oils.

for refined oils.

$M-B, M I M-B$ and MD-B for bleached oils.

Treatment II: Sodium silicate treatment followed by conventional refining and bleaching of crude oil.

Crude cottonseed oil from M, MIM or MD $(25 \mathrm{~g})$ was treated with sodium silicate, then refined and bleached.

Symbols for these oils are:

M-S, MIM-S and MD-S

for silicate treated crude oils.

M-SR, MIM-SR and MD-SR for silicate treated refined oils.

M-SB, MIM-SB and MD-SB for silicate treated bleached oils.

Treatment III: Colour-fixed oil subjected to conventional refining and bleaching.

Crude cottonseed oil from M, MIM, or MD $(25 \mathrm{~g})$ was subjected to accelerated colour fixation treatment $\left(60^{\circ} \mathrm{C} / 15\right.$ days), then refined and bleached.

Symbols for these oils are:

$M-X C, M I M-X C, M D-X C$ for fixed crude oils.

M-XR, MIM-XR, MD-XR for fixed refined oils.

$M-X B, M I M-X B, M D-X B$ for fixed bleached oils.

Treatment IV: Colour-fixed oil treated with sodium silicate then subjected to conventional refining and bleaching.

Colour-fixed crude oil $(25 \mathrm{~g})$ was first treated with sodium silicate, then refined and bleached.

Symbols for these oils are:

M-XS, MIM-XS, MD-XS for fixed crude oils treated with silicate. 


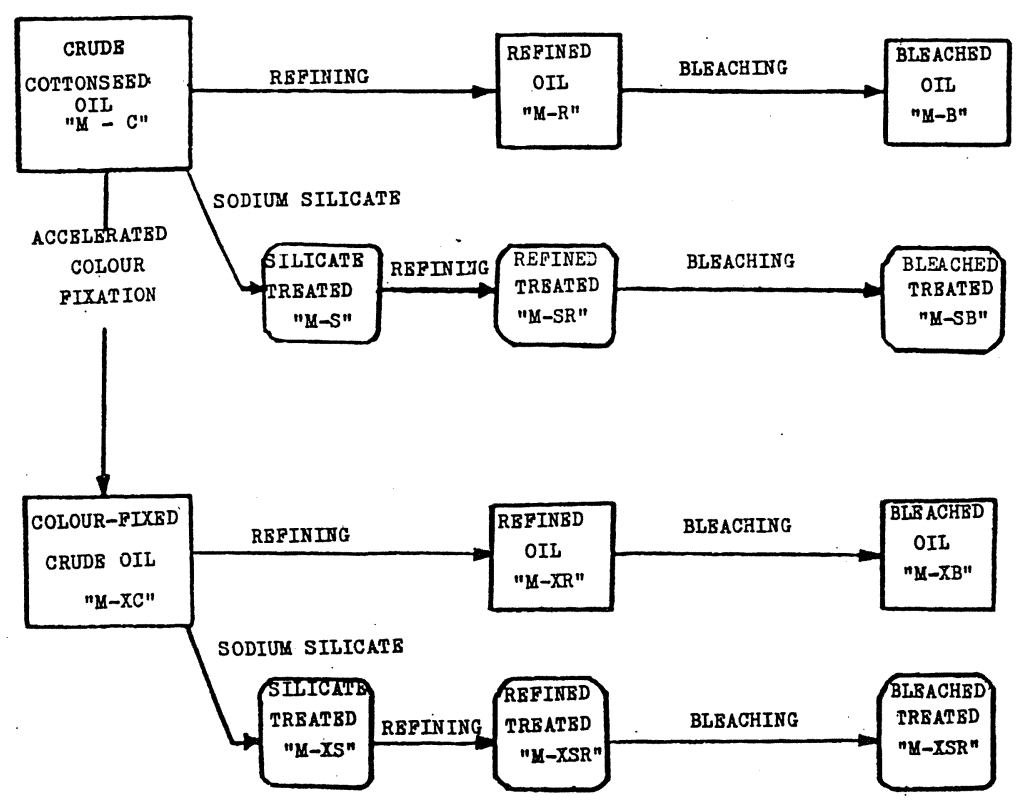

A Schematic Representation of Treatments Carried out on Mature M, 10\% Immature in Mature MIM and 10\% Damaged in Mature MD Cottonseed Oils.

Notice: In the figure, the symbol M can be substituted with MIM or MD in the case of using these oils.

\section{M-XSR, MIM-XSR, MD-XSR for fixed refined oils treated with silicate. \\ M-XSB, MIM-XSB, MD-XSB for fixed bleached oils treated with silicate.}

\section{RESULTS AND DISCUSSION}

The following illustrates the findings of the different treatments carried out on: 1.- Oil from mature cottonseed only (M). 2.- Oil from mature seed containing $10 \%$ oil from immature seed (MIM) and oil from mature seed containing $10 \%$ oil from damaged seed (MD).

\section{Treatments on oil from mature cottonseed.}

Figure $1(A, B)$ shows the absorption spectra of: the crude oil of mature cottonseed $(M-C)$, the refined oil $(M-R)$ resulting from conventional refining of the crude oil, the refined oil resulting from the sodium silicate treated crude (M-SR) and the bleached oils of the refined oils (M-B) and (M-SB). The absorption spectra of their fixed oils $(M-X C)$, (M-XR), (M-SXR), (M-XB) and (M-SXB) respectively, is also illustrated.

Crude oil M-C shows a sharp absorption band at 360 $\mathrm{nm}$ representing gossypol. Since refining results in removal of gossypol with alkali, the refined oil sample M-R do not show similar band. Refined oils with or without sodium silicate treatment M-R and M-SR show similar absorption because their original crude is presumably of prime quality since it is extracted from mature sound seed, and has not been subjected to inappropriate storage before refining.

The absorption spectra of the refined oils samples $M-R$ and M-SR reveal bands typical to carotenoid absorption at 425-430 nm, 450-455 $\mathrm{nm}$ and $480 \mathrm{~nm}$. They gave an explanation for the appearance of these bands in refined rather than crude, because the removal of gossypol pigment whose absorption is considerably greater has uncovered the underlying absorption peaks.

Tough sodium silicate treatment results in bleached oil $M-S B$ with more improved absorption than $M-B$, yet the overall absorption of both oils is typical to a good quality bleached oil. Carotenoids are removed by bleaching.

Colour fixation results in shifting in the absorption maximum of gossypol in crude oil M-X from $360 \mathrm{~nm}$ to $370 \mathrm{~nm}$. It is also clear that colour fixation results in an increase in the optical density of the crude oil at wavelengths above the $390 \mathrm{~nm}$. Also, the refined colour fixed oils $M-X R$ and M-SXR show higher absorption than their corresponding nonfixed oils $M-R$ and $M-S R$. Curves of the refined fixed oils show a shoulder at $370 \mathrm{~nm}$, presumably as a result of colour fixation. In the fixed bleached oils MXB and MXSB, the same shoulder exists between $360-380 \mathrm{~nm}$, specially in $M-X B$ sample. The curves reveal also that bleaching decreases the absorption spectra of the refined oils above $350 \mathrm{~nm}$, and sodium silicate treated crude oil gives better refined and bleached oils. $A$ small band at $430 \mathrm{~nm}$ appears only in $M-X B$ sample. This is totally eliminated by sodium silicate treatment $\mathrm{M}-\mathrm{XSB}$. 


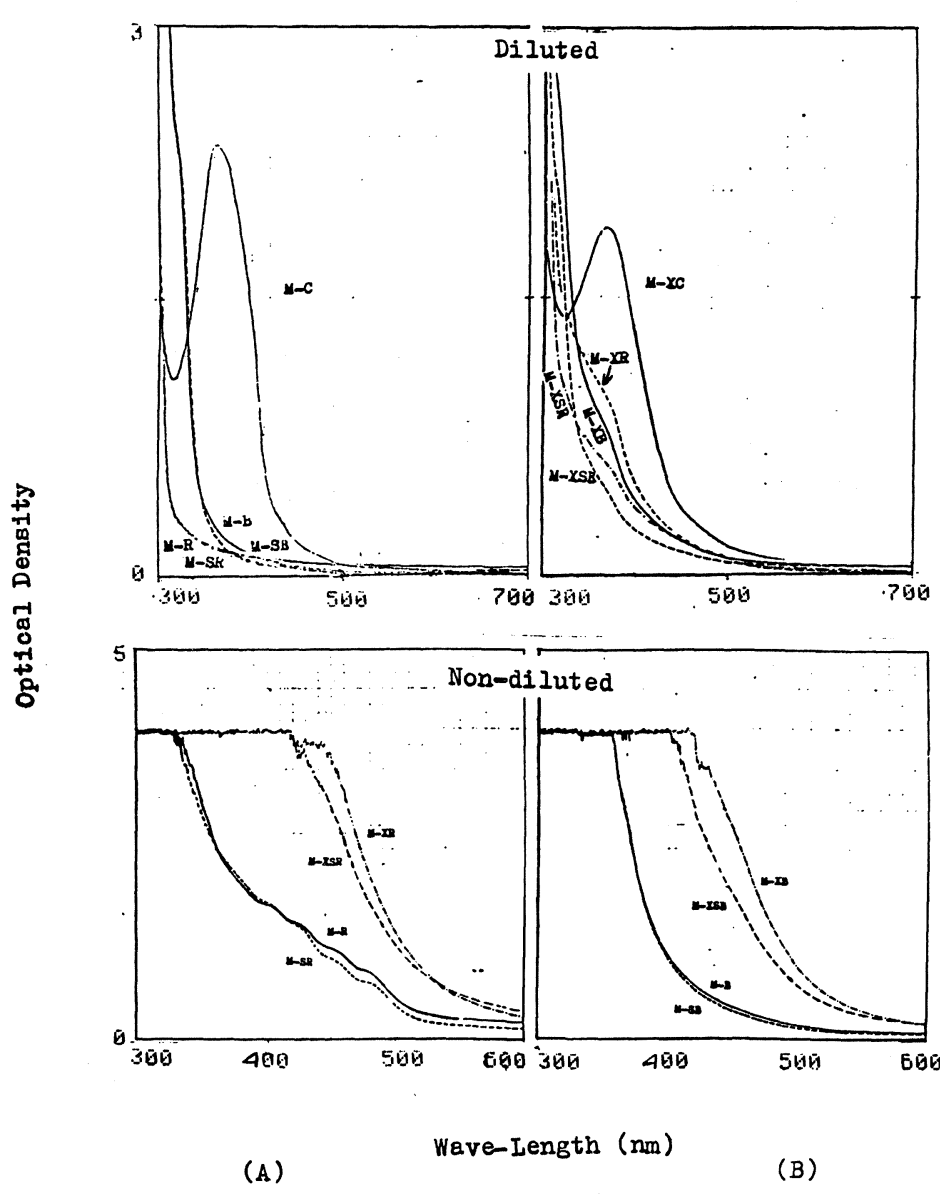

Crude, Refined \& Bleached 011s (LWC, $M-R, L-B$ ) and Sod. Pixed Crude, Refined \& Bleached 011s (L-XC, $4-X R, L x-B$ ): Sillcate Treatad 0118 (L-SR, W-SB) and Sod. S1licate Treated P1xed 0119 (W-XSR, W-XSB)

Figure 1

Absorption Spectra of Mature Cottonseed Oil (M)

Table 1

Effect of Treatments on the Colour of Oils of Mature-Sound Cottonseed

\begin{tabular}{|c|l|l|c|c|c|c|c|c|}
\hline \multirow{2}{*}{$\begin{array}{c}\text { Treatment } \\
\text { No. }\end{array}$} & Oil & Treatment & \multicolumn{2}{|c|}{ Colour-Index } & Refinability & Bleachability & $\begin{array}{c}\text { Overall } \\
\text { Effect }\end{array}$ \\
\cline { 3 - 8 } I & $\begin{array}{l}\text { Non- } \\
\text { Fixed }\end{array}$ & $\begin{array}{l}\text { Conventional } \\
\text { Refining }+ \\
\text { Bleaching }\end{array}$ & 1140 & 145.3 & 60.5 & 87.25 & 58.36 & 94.69 \\
\hline II & $\begin{array}{l}\text { Non- } \\
\text { Fixed }\end{array}$ & $\begin{array}{l}\text { Sodium } \\
\text { Silicate + } \\
\text { Conventional }\end{array}$ & 1140 & 131.1 & 53.6 & 88.50 & 59.12 & 95.30 \\
\hline III & $\begin{array}{l}\text { Colour- } \\
\text { Fixed }\end{array}$ & Conventional & 1720 & 383.9 & 317.3 & 77.68 & 17.35 & 81.55 \\
\hline IV & $\begin{array}{l}\text { Colour- } \\
\text { Fixed }\end{array}$ & $\begin{array}{l}\text { Sodium } \\
\text { Silicate+ } \\
\text { Conventional }\end{array}$ & 1720 & 350.1 & 250.9 & 79.65 & 28.33 & 85.41 \\
\hline
\end{tabular}


Table I gives the colour values cottonseed oil of mature seed,subjected to different treatments.

Crude oil extracted from mature cottonseed $M-C$ has colour index of 1140 . In treatment I conventional refining of this oil results in a refined oil $M-R$ colour of 14.5. Bleaching of this refined oil results bleached oil M-B colour of 6.1, i.e. crude oil extracted from mature sound cottonseed, responds to conventional refining and bleaching with refinability value of $87.3 \%$ and bleachability value of $58.4 \%$, and with an overall effect of $94.7 \%$. When crude oil of mature cottonseed is first treated with sodium silicate M-S prior refining (Treatment II), the crude oil M-S colour 114 leads to a refined oil M-SR colour of 13.1 and a bleached oil M-SB colour of 5.4. Refinability, bleachability and overall effect of silicate treated oil are $88.5 \%, 59.1 \%$ and $95.3 \%$ respectively. Sodium silicate treatment prior to refining leads to improvement of oil colours.

Subjecting the crude oil of mature seed to colour fixation M-XC (Treatment III) results in increase in colour to 1720 , and increase in the refined and bleached oils $M-X R$ and $M-X B$ to 383.9 and 317.3. Refinability, bleachability and overall effect are $77.7,17.4$ and 81.6 respectively.

Sodium silicate treatment of the colour fixed oil M-XS prior to refining resulted in some improvement in refined and bleached oil M-XSR and M-XSB colours 350.1 and 250.9 respectively. Refinability, bleachability and overall effect are $79.7,28.3$ and 85.4

2. Treatments on oil from mature cottonseed containing $10 \%$ oil from immature seed (MIM).

Figure $2(A, B)$ represents the absorption spectra of mixed crude oil of mature-immature seed (MIM-C), its refined oil (MIM-R), the refined oil resulting from sodium silicate treated (MIM-SR), and of bleached oils of the two refined oils (MIM-B) and (MIM-SB) and the absorption spectra of their fixed oils (MIM-XC), (MIM-XR), (MIM-XSR), (MIM-XB) and (MIM-XSB) respectively.

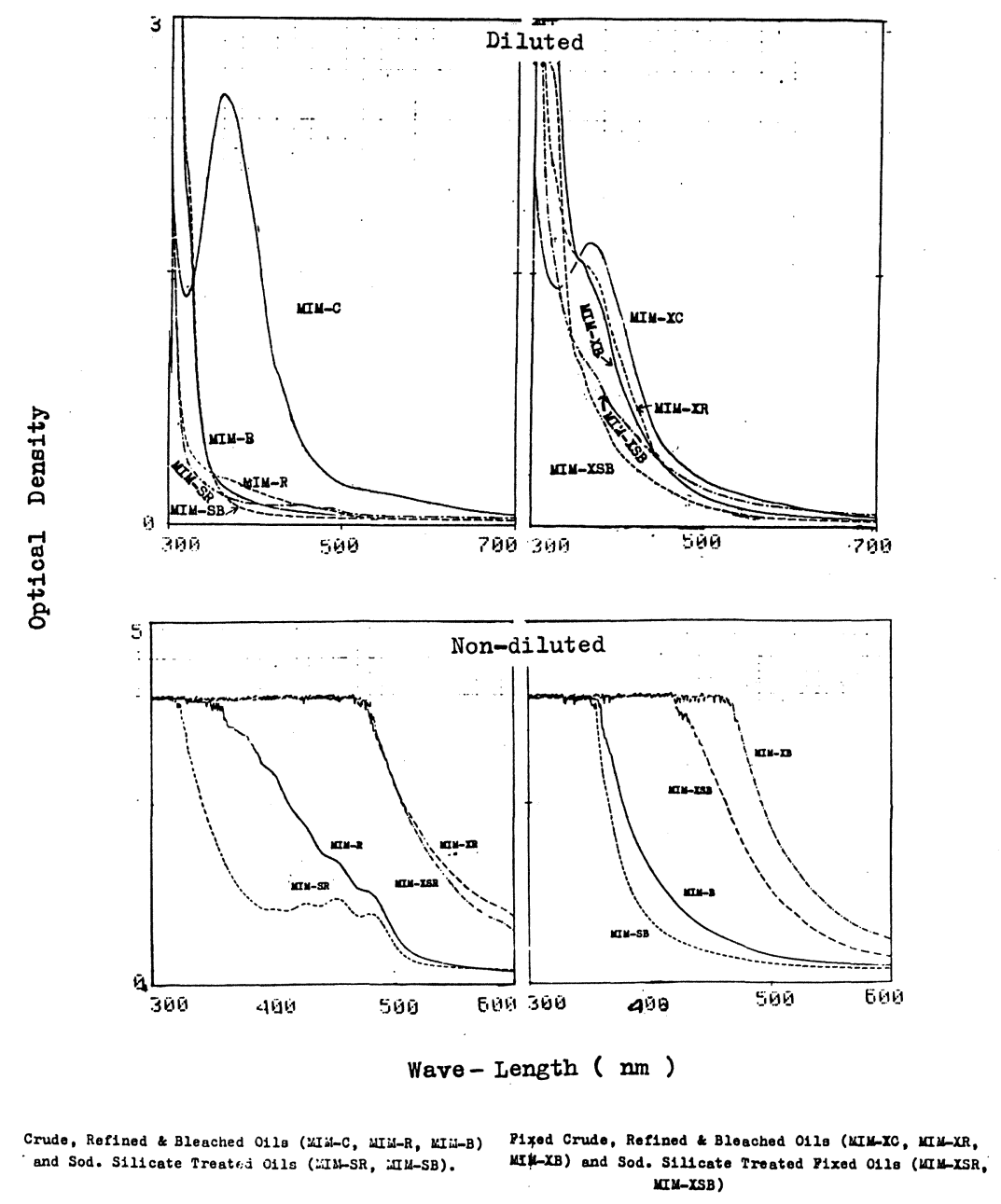

Figure 2

Absorption Spectra of $10 \%$ Immature in Mature Cottonseed Oil (MIM) 
Absorption spectra of mixed crude oil and its refined oil show higher optical densities at all wave-lengths than crude and refined oils of mature seed, however both give the sharp gossypol band at $360 \mathrm{~nm}$.

Refined sodium silicate treated mixed crude shows higher optical densities at wave-length above $480 \mathrm{~nm}$. MIM-SR gives small successive maxima of carotenoid pigments at $400,425,455$ and $480 \mathrm{~nm}$, which to be present also in MIM-R but less recognized because of the higher absorption.

The bleached oils exhibit absorption spectra similar to those of mature seed. Here also sodium silicate treatment improves the absorption characteristics (giving lower optical densities).

Carotenoid pigments are removed by bleaching. Colour fixation of the mixed crude oil results in a shift in the absorption maximum from $360 \mathrm{~nm}$ to $370 \mathrm{~nm}$. It also results in decreased absorption at wave-lengths from $320 \mathrm{~nm}$ to $410 \mathrm{~nm}$ while gives higher absorption than corresponding non-fixed oils. The colour fixation is more demonstrated in the refined crude MIM-XR with a well recognized absorption shoulder at about $370 \mathrm{~nm}$, and a slight hump at $590 \mathrm{~nm}$, it may dues to gossyfiolin. Comparing these curves with corresponding curves for mature seed oils (Table I), the effect of immature seed oil is apparent when the mixed oil is subjected to colour fixation, where considerably higher optical densities appear throughout the whole wave-length range $300-700 \mathrm{~nm}$. This is also clear in the absorption spectra of the bleached oils MIM-XB and MIM-XSB of the above two refined oils as compared with the corresponding bleached oils from mature seed.

Table II gives the colour of crude, refined and bleached oils of mature-immature cottonseed $(9: 1)$ resulted from the four treatments illustrated in a schematic representation, also gives the refinability, bleachability and the overall effect of the treatments. Comparing these data with the corresponding data in table I gives the effect of the presence of $10 \%$ oil of immature seed on the oil colour.

Table II

Effect of Treatments on the Colour of Cottonseed Oil Containing Immature Cottonseed Oil

\begin{tabular}{|c|c|c|c|c|c|c|c|c|}
\hline \multirow{2}{*}{$\begin{array}{c}\text { Treatment } \\
\text { No. }\end{array}$} & \multirow[t]{2}{*}{ Oil } & \multirow[t]{2}{*}{ Treatment } & \multicolumn{3}{|c|}{ Colour-Index } & \multirow[t]{2}{*}{ Refinability } & \multirow[t]{2}{*}{ Bleachability } & \multirow{2}{*}{$\begin{array}{c}\text { Overall } \\
\text { Effect }\end{array}$} \\
\hline & & & Crude & Refined & Bleached & & & \\
\hline 1 & $\begin{array}{l}\text { Non- } \\
\text { Fixed }\end{array}$ & Conventional & 2155 & 210.3 & 104.0 & 90.24 & 50.55 & 95.17 \\
\hline II & $\begin{array}{l}\text { Non- } \\
\text { Fixed }\end{array}$ & $\begin{array}{l}\text { Sodium } \\
\text { Silicate + } \\
\text { Conventional }\end{array}$ & 2155 & 125.2 & 59.8 & 94.19 & 52.24 & 97.23 \\
\hline III & $\begin{array}{l}\text { Colour- } \\
\text { Fixed }\end{array}$ & Conventional & 2125 & 518.8 & 460.8 & 75.59 & 11.18 & 78.32 \\
\hline IV & $\begin{array}{l}\text { Colour- } \\
\text { Fixed }\end{array}$ & $\begin{array}{l}\text { Sodium } \\
\text { Silicate+ } \\
\text { Conventional }\end{array}$ & 2125 & 509.7 & 354.6 & 76.01 & 30.43 & 83.31 \\
\hline
\end{tabular}

Addition of $10 \%$ crude oil from immature cottonseed to crude oil from mature seed MIM-C results in an increase of about $90 \%$ in the mixed crude oil colour (Treatment I in table I and II). Conventional refining and bleaching of this mixed crude result in $45 \%$ and $75 \%$ higher in refined oil MIM-R bleached oil MIM-B colours respectively than from oil from mature seed.

Sodium silicate treatment of the mixed crude oil MIM-S before refining and bleaching results in refined MIM-SR and bleached MIM-SB oil colours more or less similar to those resulting from crude oil of mature cottonseed (Treatment II in tables I and II). This leads to a conclusion that sodium silicate treatment of crude cottonseed oil containing $10 \%$ of immature seed oil is highly effective in reducing the refined and bleached oil colours more or less similar to those obtained from crude cottonseed oil of mature seed.
As to the effect of presence of immature cottonseed oil on colour fixation (Treatment III in tables I and II) values for crude oil MIM-XC, refined oil MIM-XR, and bleached oil MIM-XB colours are about $24 \%, 35 \%$ and $45 \%$ respectively higher than values for colour-fixed crude oil from mature seed. Sodium silicate treatment of the mixed crude colourfixed oil MIM-SX, resulted in $30 \%$ decrease in the finished oil colour (refined/bleached), yet the presence of immature seed oil (comparing treatment IV in tables I and II) results in about $40 \%$ increase in the refined MIM-SXR and bleached MIM-SXB oil colour of fixed oil.

\section{Treatments and oil from mature cottonseed} containing $10 \%$ oil from damaged seed.

Figure $3(A, B)$ gives the absorption spectra of mixed crude oil from mature-damaged seed (MD-C), its refined oil 
(MD-R), the refined oil resulting from the sodium silicate treated crude (MD-SR) and their bleaching oils (MD-B) and (MD-SB), and the absorption spectra of their fixed oils (MD-XC, MD-XR, MD-XSR, MD-XB and MD-XSB) respectively.

Absorption spectra of mixed crude oil and the two refined oils show higher optical densities throughout the wave-length range compared to $300-700 \mathrm{~nm}$ compared to corresponding oil from mature seed. Crude mixed oil shows the $360 \mathrm{~nm}$ band typical to gossypol. This band disappears on refining with recognized absorption around $370 \mathrm{~nm}$ for the refined oil MD-R and not for MD-SR. Refined and refined sodium silicate treated oil MD-SR show small successive bands of carotenoids of the wave-lengths 400 , $425,450-455,480 \mathrm{~nm}$.

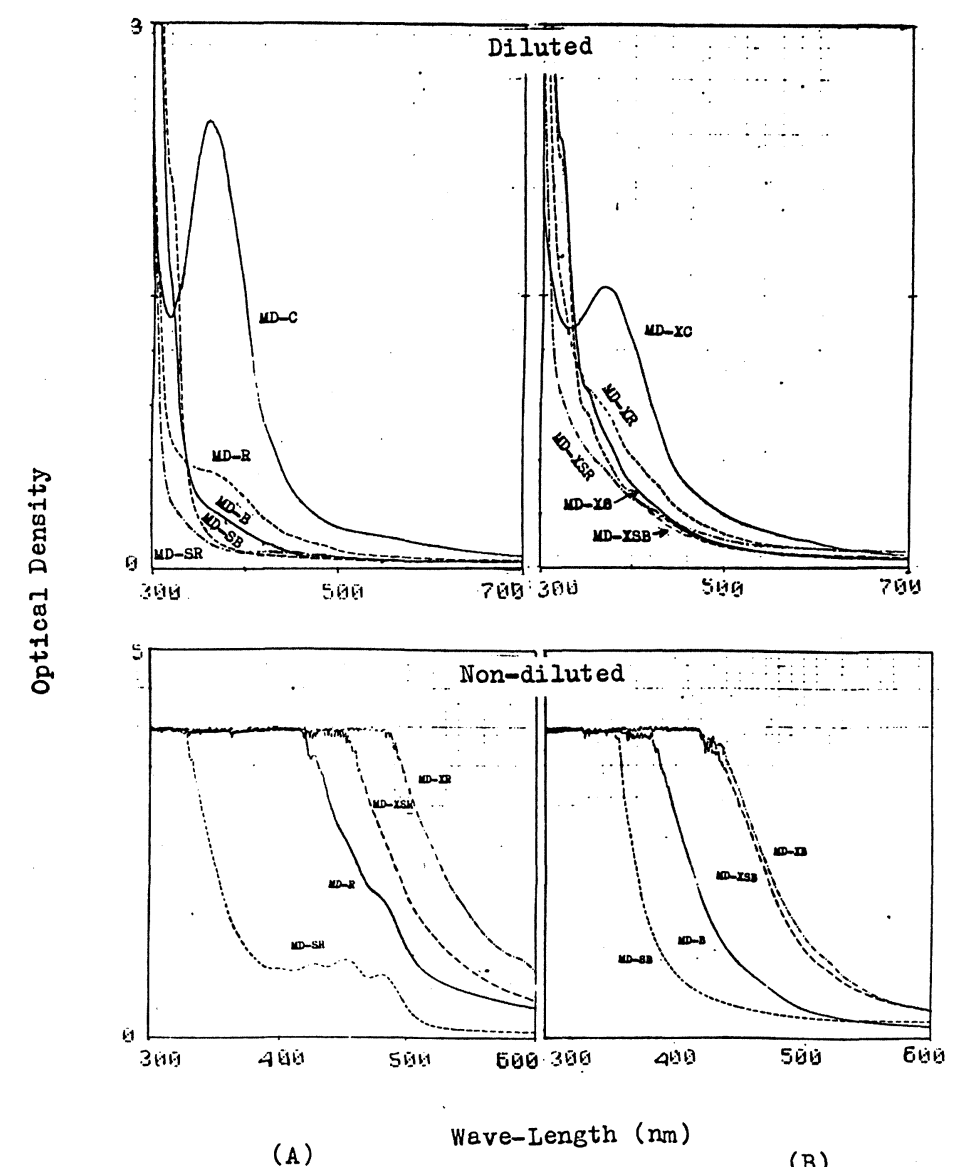

Srude, Refined \& Bleached $0110(N D-C, M D-R, A D-B)$ and P1xed Crude, Refined \& Blesched 0118 (MD-C, MD-R, UD-B) Sod. SHlicate Treated O1ls (LD-SR, MD-SB).

and Sod. S1llcate Troated O1la (2D-SR, MD-SB).

Bleaching results in reduction in the absorption. MD$B$ shows higher absorption at wave-length range about $360-420 \mathrm{~nm}$ compared to the corresponding $M-B$ and MIM-B. It is apparent that sodium silicate treatment considerably improves the absorption characteristics of the bleached oil. Carotenoid pigments have been removed by bleaching.

Colour fixation results in a shift in the $360 \mathrm{~nm}$ band to $370 \mathrm{~nm}$. It also results in refined oil with higher absorption throughout the wave-length range. Sodium silicate treatment prior to refining results in recognizable improvement in the absorption characteristics of refined and bleached oils.
Refined colour-fixe oil shows a hump at $590 \mathrm{~nm}$. Possibility exists that this band corresponds to gossyfiolin.

Table III gives the effect of the treatments illustrated in a schematic representation on the crude, refined and bleached oils from the crude oil of mature cottonseed containing $10 \%$ crude oil of damaged seed. It shows also the refinability and bleachability of oils from different treatments. Comparing these data with corresponding data in table I gives the effect of the presence of $10 \%$ damaged seed oil, and comparing the data with those in table II gives the relative effectiveness of crude oil from damaged seed to that from immature seed. 
Table III

Effect of Treatments on the Colour of Cottonseed Oil Containing Damaged Seed Oil

\begin{tabular}{|c|l|l|c|c|c|c|c|c|}
\hline \multirow{2}{*}{$\begin{array}{c}\text { Treatment } \\
\text { No. }\end{array}$} & Oil & Treatment & \multicolumn{3}{|c|}{ Colour-Index } & Refinability & Bleachability & $\begin{array}{c}\text { Overall } \\
\text { Effect }\end{array}$ \\
\cline { 3 - 7 } I & $\begin{array}{l}\text { Non- } \\
\text { Fixed }\end{array}$ & Conventional & 2030 & 332.3 & 152 & 83.63 & 54.26 & 92.51 \\
\hline II & $\begin{array}{l}\text { Non- } \\
\text { Fixed }\end{array}$ & $\begin{array}{l}\text { Sodium } \\
\text { Silicate }+ \\
\text { Conventional }\end{array}$ & 2030 & 100.0 & 62.1 & 95.07 & 37.9 & 96.94 \\
\hline III & $\begin{array}{l}\text { Colour- } \\
\text { Fixed }\end{array}$ & Conventional & 2170 & 538 & 373.1 & 75.21 & 36.65 & 82.8 \\
\hline IV & $\begin{array}{l}\text { Colour- } \\
\text { Fixed }\end{array}$ & $\begin{array}{l}\text { Sodium } \\
\text { Silicate+ } \\
\text { Conventional }\end{array}$ & 2170 & 518.8 & 351.3 & 76.1 & 32.29 & 83.8 \\
\hline
\end{tabular}

Addition of $10 \%$ oil from damaged cottonseed to mature seed oil results in mixed crude with colour value $78 \%$ higher than that of crude oil from mature seed (Treatment I, tables I and II). Though the colour of mixed crude oil from mature/immature seed is about $6 \%$ higher than the mixed mature/damaged seed oil, yet refined oil of damaged MD$R$ is $58 \%$ higher than immature MIM-R, bleached oil MD-B is also considerably higher (46\%). It is therefore concluded that the presence of $10 \%$ damaged cottonseed oil results in a crude oil that can not be satisfactorily refined and bleached with conventional methods.

Sodium silicate treatment of mixed crude oil (mature/damaged) MD-S prior to conventional refining and bleaching results in highly improved refined oil MD-SR and bleached oil MD-SB colours 100.0 and 62.1 respectively, compared to similar oil from mature seed.

Colour fixation of the mixed crude oil of mature/damaged cottonseed MD-XC (Treatment III) results in about $7 \%$ increase in the crude oil colour compared to non-fixed mixed crude. However, the problem exists in the refined MD-XR and the bleached MD-XB oils whose colours from the colour-fixed oils are $62 \%$ and $145 \%$ respectively higher than the non-fixed oils.

Sodium silicate treatment of the colour-fixed oil (mature/damaged) MD-SX prior to refining and bleaching does not result in considerable improvement in the refinability and bleachability value.

\section{REFERENCES}

Attia, M., Albasy, M., El-Nockrashy, A.S. and Shoeb, Z.E. (1981)."Cottonseed colour fixed pigments. Part III. Prevention of colour fixation and removal of colour-fixed pigment".- Nahrung 25, 607-615.
Bailey A.E. (1948).- “Cottonseed and cottonseed products".- 158-212 pág.Interscience Pub., N.Y.

Berardi, L.C. and Frampton, V.L. (1957).- "Note on gossypol and its relation to color fixation in cottonseed oil".- J. Am. Oil Chemists'Soc. 34, 399401.

El-Nockrashy, A.S., Zaher, F.A. and Osman, F. (1976).- "Cottonseed colour fixed pigments. Part I. Selectivity of hexane isomers".- Nahrung 20, 117124.

El-Nockrashy, A.S., Mustafa, H.M., El-Fouly, M.M. and El-Shattory, Y. (1976).- "Biochemical changes in cottonseed during development and maturity".- Nahrung 20, 125-132.

Fash, R.H (1934).- "Crude bollie cottonseed oil. Upon the color of refined oil from stored crude cottonseed oil".- Oil and Soap 11, 106.

Helmy, H.E. (1985).- Ph. D. Thesis, Fac. of Agric. Ain Shams Univ. Cairo, Egypt.

The Official and Tentative Methods of the A.O.C.S., 1980.

Osman, F., Zaher, F.A. and El-Nockrashy, A.S. (1976).-" "Cottonseed colour fixed pigments. Part II. Role of hexane isomers on oil quality".- Nahrung 20, 475-482.

Pons, W.A. Jr., Berardi, L.C. and Frampton, V.L. (1959).- "Kinetic study of gossypol fixation in cottonseed oil".- J. Am. Oil Chemists'Soc. 36, 337339.

Pons, W.A. Jr. (1960).- "Proceedings of ninth cottonseed processing". Clinic. Feb. 15-16, S.R.R.L., U.S.D.A., New Orleans, La.

Pons, W.A. Jr., Kuck, J.C. and Frampton, V.L. (1960).- "Color index for cottonseed oils".- J. Am. Oil Chemists'Soc. 37, 671-673.

Pons, W.A. Jr., Kuck, J.C. and Frampton, V.L. (1962).- May 22, U.S. 3, 036102.

Attia, M., Taha, F.S., Mustafa, H.M. and El-Nockrashy, A.S. (1988)."Bench-scale treatments of colour-fixed cottonseed oil".- Nahrung 32 281-284.

Williams, P.A., Boatner, C.H., Hall, C.M., O'Connor, R.T. and Castillon, L.E. (1947).- "Processing of cottonseed. III Color development in cottonseed oil during storage of the seed and crude oil".- J. Am. Oil Chemists'Soc. 24, 363-369.

(Recibido: Septiembre 1993) 